\title{
Effect of Different Herbicides on Floral and Yield Parameters in China aster (Callistephus chinensis (L.) Nees)
}

\author{
K. Nagapushpa*, M. Vijaya, K.B. Suneetha Devi, A. Girwani and Veena Joshi \\ College of Horticulture, Sri Konda Laxman Telangana State Horticultural University, \\ Rajendra nagar, Hyderabad, 500030, Telangana, India \\ *Corresponding author
}

\begin{tabular}{|c|}
\hline Keywords \\
\hline $\begin{array}{l}\text { China aster, } \\
\text { Herbicides, Hand } \\
\text { weeding, Number of } \\
\text { flowers, Flower yield }\end{array}$ \\
\hline Article Info \\
\hline $\begin{array}{l}\text { Accepted: } \\
22 \text { April } 2018 \\
\text { Available Online: } \\
10 \text { May } 2018\end{array}$ \\
\hline
\end{tabular}

An experiment was conducted during 2016-2017 at College of Horticulture SKLTSHU Rajendranagar, Hyderabad. The experiment was conducted in randomized block design with factorial concept with three replications. Factor I includes two varieties Kamini $\left(\mathrm{V}_{1}\right)$ and Poornima $\left(\mathrm{V}_{2}\right)$, factor II includes eight treatments viz., Pendimethalin (30EC), Oxyfluorfen (25EC) and Alachlor (50EC) as pre emergence herbicides in combination with Quizalofop ethyl (10EC) as post emergence followed by hand weeding at 20 DAT. The results revealed pendimethalin $0.1 \mathrm{~kg}$ a.i ha ${ }^{-1}$ followed by hand weeding at 30 DAT recorded significantly increased, number of flowers, yield and quality of flowers. This was followed by alachlor $0.1 \mathrm{~kg}$ a.i ha ${ }^{-1}$ followed by hand weeding at 30 DAT. While, unweeded control gave poor control of weeds and reduced plant growth, yield and quality of flowers. Days to first flower opening, 50\% flowering, duration of flowering, flower diameter, fresh weight of flower, number of flowers plant ${ }^{-1}$, flower yield plant ${ }^{-1}(\mathrm{~g})$ and $\mathrm{t}$, and vase life exhibited maximum with pendimethalin (30EC) @ $1.0 \mathrm{~kg} \mathrm{a.i} \mathrm{ha}^{-1}$ followed by hand weeding. Which was followed by alachlor (50EC) @ $1.0 \mathrm{~kg} \mathrm{a}^{\mathrm{i}} \mathrm{ha}^{-1}$ followed by hand weeding. Minimum days to first flower opening and 50\% flowering were observed in Kamini, while Poornima has recorded maximum duration of flowering. Flower diameter, fresh weight of flower and flower yield plant- ${ }^{1}(\mathrm{~g})$.

\section{Introduction}

China aster [Callistephus chinensis (L). Ness] a member of the family Asteraceae is one of the important commercial flower crops of our country. It is also an important commercial flower crop of Siberia, Russia, Japan, North America, Switzerland and Europe. It is native to China and has spread to Europe and other tropical countries during 1731 AD. Aster can be grown successfully in open conditions. Its flowers are used for various purposes. Cut asters last long and are used in vases and flower decoration. It is also used in the preparation of bouquets, garlands, etc. It is very popular as a bedding plant and they are also used to grow as potted plants. Dwarf types are suitable for edges and used as herbaceous border plant in parks and gardens. The science of weed control has advanced considerably during the past two decades. A number of herbicides have become available in the market for control of weeds in flower crops. However, detailed information on this 
choice of herbicides, their appropriate dosage and time of application is not fully available to the farmer's usage. Considering the economic importance of China aster, the present study was taken up with the following objective.

\section{Materials and Methods}

The study was conducted in College of Horticulture, Sri Konda Laxman Telangana State Horticultural University, Rajendra nagar, Hyderabad, during 2016-2017 using China aster var. Kamini and Poornima. The soil was red sandy loam in nature. The experimental design was FRBD with three replications. The raised nursery beds were sown in lines and covered with a layer of soil and watered regularly with rose can. Four weeks old healthy and uniform seedlings were transplanted in well-prepared plots of $3 \times 3 \mathrm{~m}^{2}$, at a distance of $30 \times 30 \mathrm{~cm}$. The recommended dose of fertilizers was applied in the form of urea, single super phosphate and Muriate of potash respectively. At the time of transplanting, half dose of $\mathrm{N}$ and full dose of $\mathrm{P}$ and $\mathrm{K}$ were applied in a circular band of about 3-4 $\mathrm{cm}$ around each plant and the crop was top dressed with remaining half dose of $\mathrm{N}$ after 30 days of transplanting.

The details of the treatments were as follows $\mathrm{T}_{1}$ - Pendimethalin (30 EC) as pre- emergence @ $1.0 \mathrm{~kg}$ a.i ha ${ }^{-1}$ followed by hand weeding at 30 DAT, T $2^{-}$Pendimethalin (30 EC) as pre emergence @ $1.0 \mathrm{~kg}$ a.i ha ${ }^{-1}$ followed by Quizalofop ethyl (10 EC) as post emergence @ $50 \mathrm{~g}$ a.i ha ${ }^{-1}$ at 15 DAT, T3-Oxyfluorfen (25 EC) pre-emergence @ $0.15 \mathrm{~kg}$ a.i $\mathrm{ha}^{-1}$ followed by hand weeding at $30 \mathrm{DAT}, \mathrm{T}_{4}$ Oxyfluorfen (25 EC) as pre-emergence @ $0.15 \mathrm{~kg}$ a.i ha ${ }^{-1}$ followed by Quizalofop ethyl (10 EC) as post emergence @ $50 \mathrm{~g} \mathrm{a.i} \mathrm{ha}{ }^{-1}$ at 15 DAT, T- $^{-}$Alachlor (50 EC) as preemergence@1.0 kg a.i ha ${ }^{-1}$ followed by hand weeding at $30 \mathrm{DAT}^{\mathrm{DA}} \mathrm{T}_{6}$ - Alachlor (50 EC) as pre-emergence@1.0 kg a.i ha ${ }^{-1}$ followed by
Quizalofop ethyl as post emergence @ $50 \mathrm{~g}$ a.i $\mathrm{ha}^{-1}$ at $15 \mathrm{DAT}_{7} \mathrm{~T}_{7}$ - Farmer practices (Hand weeding at 20 and 40 days after transplanting), $\mathrm{T}_{8}$ - Unweeded control.

The data ondays to first flower opening and $50 \%$ flowering, duration of flowering were noted in different treatments. Flower diameter, weight of flower, number of flowers and flower yield were measured at the time of harvest and statistically analysed.

\section{Results and Discussion}

Effect of different pre-emergence herbicides on days taken to first flower appearance was studied and presented in table 1 . It was found that all the treatment showed significant differences with regard to number of days required for appearance of first flower opening. The least number of days taken for first flower opening (53.9 days) was recorded in pendimethalin @ $1.0 \mathrm{~kg}$ a.i ha ${ }^{-1}+$ hand weeding treatment. The maximum number of days to first bud appearance was observed in unweeded control (62.8 days). Among the two varieties, Kamini recorded minimum days to first flower opening (50.4 days) compared with Poornima (64.2 days). Interaction effects between the varieties, and weed control treatments noticed that Kamini variety along with pendimethalin + hand weeding treatment minimum days to taken first flower opening (45.5 days).

It is due to reduction in weed population and right from the initial stages of plant growth. In unweeded control for opening of flowering was late. This may be because of severe infestation of weeds that resulted in competition (Singh and Kavita, 2005) in rose. There was marked difference in days taken for first flower's opening among the different weed control treatments. Similar results were reported in China aster (Vinaykumar and Gowda, 2011). 
The number of days to $50 \%$ flowering differed significantly among weed control treatments and varieties. The minimum days to $50 \%$ flowering (65.6 days) was observed in pendimethalin @ $1.0 \mathrm{~kg}$ a.i ha ${ }^{-1}+$ hand weeding plot. Among the two varieties, Kamini observed minimum days to $50 \%$ flowering (64.1 days) compared with Poornima (75.6 days). Interaction effects between the varieties, and weed control treatments reported that Kamini variety along with pendimethalin + hand weeding produced minimum days to $50 \%$ flowering (60.4 days). Significant difference in number of days taken for $50 \%$ flowering was noticed in all the weed control treatments (Table 1). The treatments, pendimethalin as pre-emergence + hand weeding and alachlor as pre-emergence + hand weeding were early to reach 50 per cent flowering. Vinaykumar and Gowda (2011) reported that hand weeding thrice recorded less number of days to reach full bloom stage in China aster. Other treatments slightly delayed 50 per cent flowering. Treatment unweeded control was late to reach 50 per cent flowering than other treatments, because of weak growth due to severe competition from weeds. More time to reach full bloom stage in unweeded control was also reported by Shalini and Patil (2006) in gerbera and Vijaykumar Kori and Patil (2003) in gladiolus.

Data regarding duration of flowering was obtained and presented in table 1. Significant effect of different herbicides on duration of flowering was recorded. Delay in flowering was observed with different treatments of herbicides over control. There was statistically significant difference in duration of flowering within higher and lower herbicide application of all four herbicides.

Among the weed control treatments the longest flowering duration was reported from pendimethalin@1.0 kg a.i ha ${ }^{-1}+$ hand weeding (32.0 days). The shortest flowering duration among the different herbicide treatments was recorded in unweeded control (23.5 days). Among the two varieties, Poornima recorded longest duration of flowering noticed (30.8 days) compared with Kamini (25.7 days). Interaction effects between the varieties, and weed control treatments reported that Poornima variety along with pendimethalin + hand weeding treatment longest duration of flowering at (34.2 days). It is due to less competition of weeds for nutrients (Extended period of flowering due to availability of nutrients for longer period is in accordance with Pal and Das (1990). Minimum flower duration was recorded in unweeded control, due to more competition of weeds for metabolites. It was also reported by Singh and Kavita (2005) and Vijaykumar Kori and Patil (2003).

Effect of different pre-emergence herbicides on flower diameter was studied and presented in and table 2. There was significant difference between the different herbicidal treatments and varieties. Among the different herbicides tried, the maximum flower diameter $(6.0 \mathrm{~cm})$ was recorded from pendimethalin@1.0 kg a.i ha ${ }^{-1}+$ hand weeding treatment. Among the two varieties, Kamini recorded maximum flower diameter noticed $(5.4 \mathrm{~cm})$ compared with Poornima $(4.7 \mathrm{~cm})$. Interaction effects between the varieties, and weed control treatments reported that Kamini variety along with from pendimethalin + hand weeding treatment observed maximum flower diameter $(6.4 \mathrm{~cm})$.

The maximum flower diameter pendimethalin + hand weeding treatment $(6.1 \mathrm{~cm})$ were recorded in China aster. This was due to better utilization of more photosynthesis which was accumulated due to more number of leaves and because of better control of the weeds. Similar to our findings, results has also been reported by Shalini and Patil (2006) in gerbera. 
Table.1 Effect of weed control treatments on days to first flower opening, days to $50 \%$ flowering and duration of flowering (days) in China aster

\begin{tabular}{|c|c|c|c|c|c|c|c|c|c|}
\hline \multirow{3}{*}{ Treatments } & \multicolumn{9}{|c|}{ Days after transplanting } \\
\hline & \multicolumn{2}{|c|}{ Days to first flower opening } & \multirow{2}{*}{$\begin{array}{c}\text { Treatment } \\
\text { mean }\end{array}$} & \multicolumn{2}{|c|}{ Days to $50 \%$ flowering } & \multirow{2}{*}{$\begin{array}{c}\text { Treatment } \\
\text { mean }\end{array}$} & \multicolumn{2}{|c|}{ Duration of flowering (days) } & \multirow{2}{*}{$\begin{array}{c}\text { Treatment } \\
\text { mean }\end{array}$} \\
\hline & $\operatorname{Kamini}\left(\mathbf{V}_{1}\right)$ & $\begin{array}{c}\text { Poornima } \\
\left(\mathbf{V}_{2}\right)\end{array}$ & & $\operatorname{Kamini}\left(\mathbf{V}_{1}\right)$ & $\begin{array}{c}\text { Poornima } \\
\left(\mathbf{V}_{2}\right)\end{array}$ & & Kamini $\left(V_{1}\right)$ & $\begin{array}{c}\text { Poornima } \\
\left(\mathbf{V}_{2}\right)\end{array}$ & \\
\hline $\mathbf{T}_{1}$ & 45.5 & 60.9 & 53.2 & 60.4 & 70.7 & 65.6 & 29.7 & 34.2 & 32.0 \\
\hline $\mathbf{T}_{2}$ & 49.2 & 63.5 & 56.4 & 63.5 & 75.4 & 69.5 & 26.8 & 31.7 & 29.3 \\
\hline $\mathbf{T}_{\mathbf{3}}$ & 52.3 & 65.2 & 58.8 & 65.5 & 77.6 & 71.6 & 24.4 & 29.3 & 26.9 \\
\hline$\overline{T_{4}}$ & 54.6 & 67.1 & 60.9 & 66.7 & 78.6 & 72.7 & 23.1 & 28.3 & 25.7 \\
\hline$\overline{T_{5}}$ & 46.0 & 61.4 & 53.7 & 61.2 & 72.5 & 66.9 & 28.6 & 33.5 & 31.1 \\
\hline $\mathrm{T}_{6}$ & 50.5 & 64.6 & 57.6 & 64.4 & 76.5 & 70.5 & 25.2 & 30.6 & 27.9 \\
\hline$\overline{T_{7}}$ & 47.9 & 62.4 & 55.2 & 62.2 & 73.3 & 67.8 & 27.4 & 32.2 & 29.8 \\
\hline$\overline{T_{8}}$ & 56.8 & 68.7 & 62.8 & 68.6 & 79.8 & 74.2 & 20.2 & 26.7 & 23.5 \\
\hline $\begin{array}{l}\text { Variety } \\
\text { Mean }\end{array}$ & 50.4 & 64.2 & & 64.1 & 75.6 & & 25.7 & 30.8 & \\
\hline
\end{tabular}

\begin{tabular}{|l|c|c|c|c|c|c|}
\hline & SEm \pm & CD at 5\% & SEm \pm & CD at 5\% & SEm \pm \\
\hline Variety(V) & 0.45 & 1.31 & 0.35 & 1.03 & 0.02 & 0.07 \\
\hline Treatment (T) & 0.91 & 2.63 & 0.71 & 2.06 & 0.05 & 0.15 \\
\hline Interaction & 1.29 & 3.72 & 1.01 & 3.03 & 0.07 \\
\hline$(\mathbf{V x T})$ & & & & 0.22 \\
\hline
\end{tabular}


Table.2 Effect of weed control treatments on Flower diameter $(\mathrm{cm})$.fresh weight of flower $(\mathrm{g})$ number of flowers plant ${ }^{-1}$ in China aster

\begin{tabular}{|c|c|c|c|c|c|c|c|c|c|}
\hline \multirow{3}{*}{ Treatments } & \multicolumn{9}{|c|}{ Days after transplanting } \\
\hline & \multicolumn{2}{|c|}{ Flower diameter (cm) } & \multirow{2}{*}{$\begin{array}{c}\text { Treatment } \\
\text { mean }\end{array}$} & \multicolumn{2}{|c|}{ Fresh weight of flower(g) } & \multirow{2}{*}{$\begin{array}{c}\text { Treatment } \\
\text { mean }\end{array}$} & \multicolumn{2}{|c|}{ Number of flowers plant ${ }^{-1}$} & \multirow{2}{*}{$\begin{array}{c}\text { Treatment } \\
\text { mean }\end{array}$} \\
\hline & $\operatorname{Kamini}\left(\mathbf{V}_{1}\right)$ & $\begin{array}{c}\text { Poornima } \\
\left(\mathbf{V}_{2}\right)\end{array}$ & & Kamini $\left(V_{1}\right)$ & $\begin{array}{l}\text { Poornima } \\
\qquad\left(V_{2}\right)\end{array}$ & & $\operatorname{Kamini}\left(\mathbf{V}_{1}\right)$ & $\begin{array}{l}\text { Poornima } \\
\qquad\left(V_{2}\right)\end{array}$ & \\
\hline $\mathbf{T}_{1}$ & 6.4 & 5.8 & 6.0 & 5.0 & 3.8 & 4.4 & 43.3 & 39.6 & 41.5 \\
\hline $\mathbf{T}_{2}$ & 5.7 & 4.9 & 5.3 & 4.4 & 3.5 & 4.0 & 38.1 & 35.4 & 36.8 \\
\hline$\overline{T_{3}}$ & 5.2 & 4.5 & 4.9 & 3.9 & 3.1 & 3.5 & 35.5 & 32.5 & 34.0 \\
\hline $\mathbf{T}_{4}$ & 5.0 & 4.4 & 4.7 & 3.5 & 3.0 & 3.3 & 33.7 & 30.2 & 32.0 \\
\hline$\overline{T_{5}}$ & 6.2 & 5.3 & 5.9 & 4.8 & 3.7 & 4.3 & 41.2 & 38.9 & 40.1 \\
\hline $\mathrm{T}_{6}$ & 5.5 & 4.6 & 5.1 & 4.0 & 3.3 & 3.7 & 37.8 & 34.8 & 36.3 \\
\hline$\overline{T_{7}}$ & 5.9 & 5.0 & 5.5 & 4.6 & 3.6 & 4.1 & 40.5 & 37.2 & 38.9 \\
\hline $\mathbf{T}_{8}$ & 4.7 & 4.2 & 4.5 & 3.3 & 2.7 & 3.0 & 29.4 & 25.8 & 27.6 \\
\hline $\begin{array}{l}\text { Variety } \\
\text { Mean }\end{array}$ & 5.4 & 4.7 & & 4.2 & 3.3 & & 37.4 & 34.3 & \\
\hline & \multicolumn{2}{|c|}{ SEm \pm} & DD at $5 \%$ & \multicolumn{2}{|c|}{ SEm \pm} & $D$ at $5 \%$ & \multicolumn{2}{|l|}{ SEm \pm} & CD at $5 \%$ \\
\hline Variety(V) & \multicolumn{2}{|c|}{0.12} & 0.36 & \multicolumn{2}{|l|}{0.09} & 0.28 & \multicolumn{2}{|l|}{0.92} & 2.76 \\
\hline Treatment ( & \multicolumn{2}{|c|}{0.25} & 0.72 & \multicolumn{2}{|l|}{0.19} & 0.56 & \multicolumn{2}{|l|}{1.84} & 5.31 \\
\hline $\begin{array}{l}\text { Interaction } \\
(\mathbf{V x T})\end{array}$ & \multicolumn{2}{|c|}{0.35} & 1.05 & \multicolumn{2}{|l|}{0.27} & 0.81 & \multicolumn{2}{|l|}{2.60} & 7.80 \\
\hline
\end{tabular}


Table.3 Effect of weed control treatments on flower yieldplant ${ }^{-1}(\mathrm{~g})$ flower yield $\mathrm{t} \mathrm{ha}^{-1}$ in China aster

\begin{tabular}{|c|c|c|c|c|c|c|c|}
\hline \multirow{2}{*}{ Treatments } & \multicolumn{2}{|c|}{ Flower yield plant ${ }^{-1}(\mathrm{~g})$} & \multirow[t]{2}{*}{ Treatment mean } & \multirow[t]{2}{*}{ Treatments } & \multicolumn{2}{|c|}{ Flower yield $\mathrm{t} \mathrm{ha} \mathrm{h}^{-1}$} & \multirow{2}{*}{$\begin{array}{c}\text { Treatment } \\
\text { mean }\end{array}$} \\
\hline & Kamini $\left(\mathbf{V}_{1}\right)$ & $\begin{array}{c}\text { Poornima } \\
\left(\mathbf{V}_{2}\right)\end{array}$ & & & $\operatorname{Kamini}\left(\mathbf{V}_{1}\right)$ & Poornima $\left(V_{2}\right)$ & \\
\hline$\overline{T_{1}}$ & 216.5 & 150.4 & 183.5 & $\mathbf{T}_{1}$ & 6.0 & 4.2 & 5.1 \\
\hline$\overline{T_{2}}$ & 167.6 & 123.9 & 145.8 & $\mathbf{T}_{2}$ & 4.6 & 3.4 & 4.0 \\
\hline$\overline{T_{3}}$ & 138.4 & 100.7 & 116.5 & $\mathbf{T}_{\mathbf{3}}$ & 3.8 & 2.7 & 3.3 \\
\hline$\overline{T_{4}}$ & 117.9 & 90.6 & 117.3 & $\mathbf{T}_{4}$ & 3.2 & 2.5 & 2.9 \\
\hline$\overline{T_{5}}$ & 197.7 & 143.9 & 163.2 & $\mathbf{T}_{5}$ & 5.4 & 3.9 & 4.7 \\
\hline$\overline{T_{6}}$ & 151.2 & 114.8 & 134.5 & $\mathbf{T}_{6}$ & 4.1 & 3.1 & 3.6 \\
\hline$\overline{\mathbf{T}_{7}}$ & 186.3 & 133.9 & 160.1 & $\mathbf{T}_{7}$ & 5.1 & 3.7 & 4.4 \\
\hline $\mathrm{T}_{8}$ & 97.1 & 69.6 & 83.4 & $\mathbf{T}_{8}$ & 2.6 & 1.9 & 2.3 \\
\hline \multirow[t]{2}{*}{ Variety mean } & 159.1 & 116.9 & & Variety mean & 4.4 & 3.2 & \\
\hline & \multicolumn{2}{|c|}{$\mathrm{SE} \mathrm{m} \pm$} & CD at $5 \%$ & & $\mathrm{SE} \mathrm{m} \pm$ & \multicolumn{2}{|c|}{ CD at $5 \%$} \\
\hline Variety(V) & \multicolumn{2}{|c|}{05.1} & 14.9 & Variety(V) & 0.04 & \multicolumn{2}{|c|}{0.14} \\
\hline Treatment(T) & \multicolumn{2}{|c|}{10.3} & 29.8 & Treatment(T) & 0.07 & \multicolumn{2}{|c|}{0.21} \\
\hline Interaction (VxT) & \multicolumn{2}{|c|}{14.6} & 43.8 & $\begin{array}{l}\text { Interaction } \\
(\mathbf{V x T})\end{array}$ & 0.06 & \multicolumn{2}{|c|}{0.18} \\
\hline
\end{tabular}


The data pertaining different weed control treatments influencing the fresh weight of flower (g) were presented in table 2. Among the weed treatments, fresh weight of flower (g) was maximum in pendimethalin @ 1.0 kg a.i $\mathrm{ha}^{-1}+$ hand weeding $(4.4 \mathrm{~cm})$. Minimum fresh weight of flower was recorded in unweeded control $(3.0 \mathrm{~cm})$. Among the two varieties, Kamini recorded maximum weight of flower $(3.3 \mathrm{~cm})$ compared with Poornima $(3.3 \mathrm{~cm})$. Interaction effects between the varieties, and weed control treatments reported that Kamini variety along with pendimethalin + hand weeding treatment noticed maximum fresh weight of flower (5.0 $\mathrm{cm})$.

The maximum fresh weight of flower was recorded in (Table 2.) treatment plot treated with Pendimethalin as pre-emergence + hand weeding. More fresh weight of flower was obtained in Pendimethalin + hand weeding treatment in China aster (Vinaykumar and Gowda 2011). Increase in single flower weight may be due to more accumulation of metabolites in flower. These results are in accordance with the studies of Dutta et al., (1993), in chrysanthemum. More accumulation of metabolites in flower due to less weeds competition. Minimum flower weight was recorded in unweeded control, due more competition of weeds for metabolites. It was also reported by Singh and Kavita (2005) and Vijaykumar Kori and Patil (2003).

Different weed control treatments influencing thenumber of flowers plant ${ }^{-1}$ was presented in table 2. Among the different pre-emergence herbicides, the highest number of flowers (41.5) was recorded from pendimethalin @ 1.0 $\mathrm{kg}$ a.i $\mathrm{ha}^{-1}+$ hand weeding. Among the two varieties, Kamini recorded maximum number of flowers (37.4) compared with Poornima (34.3). Interaction effects between the varieties, and weed control treatments reported that Kamini variety along with pendimethalin + hand weeding treatment maximum number of flowers at (43.3). Maximum no. of flowers plant ${ }^{-1}$ was obtained in treatment pendimethalin followed by hand weeding. Marked increase in number of flowers plant ${ }^{-1}$ was due to the fact that the crop plants in these treatments experienced good vegetative growth right from the early stages of growth period because of less competition by weeds for nutrients, water, space, sunlight and nutrients which might have resulted in higher photosynthetic activity and no phytotoxic effect and higher number of flowers plant ${ }^{-1}$. Similar results were also observed in gerbera (Shalini and Patil, 2006) and in gladiolus (Vijayakumar Kori and Patil, 2003).

Different weed control treatments influencing theflower yieldplant ${ }^{-1}(\mathrm{~g})$ at each picking were presented in table 3. Significant difference was noticed regarding flower yieldplant ${ }^{-1}$ (Table 3). Treatment pendimethalin + hand weeding recorded significantly higher flower yieldplant $^{-1}(183.5 \mathrm{~g})$, which was followed by alachlor + hand weeding (163.2 and 160.1) significantly superior to hand weeding, two pre emergence herbicides like alachlor and oxyfluorfen combination with hand weeding and pre emergence herbicides followed by post emergent (quizalofop ethyl). Whereas the minimum weight of flowers plant ${ }^{-1}$ was recorded in the unweeded control $(83.4 \mathrm{~g})$. Among the two varieties, Kamini recorded maximum flower yield (159.1 g) compared with Poornima (116.9 g). Interaction effects between the varieties, and weed control treatments noticed that Kamini variety along with pendimethalin + hand weeding treatment maximum flower yield at (216.5 g). Minimum flower yield were observed in unweeded control (97.1 g). Poornima variety along with pendimethalin + hand weeding produced maximum (150.4 g). Minimum flower yield was observed in unweeded control (69.6 g). 
Pendimethalin as pre-emergence + hand weeding produced more flowers with less weight when compared to alachlor and oxyfluorfen. Higher flower yield might be attributed to the availability of nutrients, moisture and less competition from weeds for sunlight and space. The lowest yield of flowers was recorded in unweeded control obtained in weedy check. This was due to severe weed competition which ultimately resulted in lower yield. Similar results were also obtained by Swaroop et al., (2014) in gladiolus at second picking of flowers apart from this it retained to some extent causing warm and humid conditions around the plant. Thus induced to yield less flowers in terms of weight. The increase in yield of flowers plant 1 with weed free might be due to the production of large number of branches and healthy growth of plant for flower production. Similar finding were reported by Das and Mishra (2005) in African marigold. Ramkrishna (2007) observed the highest flower yield in gladiolus with the application of pendimethalin@1.5 kg ha ${ }^{-1}$.

From the table 3 and it was evident that the flower yield $\mathrm{t} \mathrm{ha}^{-1}$ varied significantly among the weed control treatments Significantly maximum flower yield of $\left(5.1 \mathrm{t} \mathrm{ha}^{-1}\right)$ was recorded in pendimethalin as pre emergence + hand weeding was statistically superior over rest of the treatments. Among the two varieties, Kamini recorded maximum flower yield $\left(4.4 \mathrm{t} \mathrm{ha}^{-1}\right)$ compared with Poornima $\left(3.2 \mathrm{t} \mathrm{ha}^{-1}\right)$. Interaction effects between the varieties, and weed control treatments reported that Kamini variety along with pendimethalin as pre emergence + hand weeding treatment maximum flower yield at $\left(6.0 \mathrm{t} \mathrm{ha}^{-1}\right)$. This was due to fact that more number of flowers $\mathrm{t} \mathrm{ha}^{-1}$. Whereas $\left(\mathrm{T}_{1}\right)$ control treatment yielded less due to higher weed count which resulted in higher competition of weeds with the crop plants which ultimately suppressed the growth and flowering of marigold. These results are in agreement with those reported by Shalini and Patil (2006) in Gerbera with application pendimethalin @ $1.5 \mathrm{~kg} \mathrm{ha}^{-1}$. Acharya et al., (2003) observed with application of pendimethalin @ $1.0 \mathrm{~kg} \mathrm{ha}{ }^{-1}$ resulted maximum flower yield in African marigold. Das and Mishra (2005) reported in African marigold.

Among all the weed control treatments the best results were obtained from China aster varieties treated with pendimethalin as preemergent + hand weeding. Between varieties, variety Kamini gave better results with less days to first flower opening, 50\% flowering, higher duration of flowering, flower diameter, weight of flower, number of flower and yield.

\section{Acknowledgement}

The authors would like to thank the Head, College of Horticulture, Sri Konda Laxman Telangana State Horticultural University, Rajendra nagar, Hyderabad. Telangana State for providing necessary facilities.

\section{References}

Acharya, M. M, 2003. Effect of nitrogen phosphorus and weed control on growth, flowering and yield of African marigold (Tagetes erecta L.) Indian perf. 87(1): 40-45.

Das, S. N. and Mishra, H. M. 2005.Studies on graded doses of Fertilizers and herbicides, polyethene mulches on growth, flowering and yield of African marigold (Tagetes erecta L). The Orissa Journal of Horticulture. 33 (2): 42-48.

Dutta J P Seemanthini Ramadas and Md. Abdul Khader 1993 Regulation of flowering by growth regulators in chrysanthemum (Chrysanthemum indicum Linn.) cv. Co.1.South Indian Horticulture 41(5): 293-299. 
Pal, A. K and Das, S. N. 1990. Effect of weedicides on growth and flowering of tuberose. South Indian Horticulture. 38(3): 143-149.

Shalini, M and Patil, V. S. 2006. Effect of Integrated weed management practices on in gerbera. Karnataka. J. Agri. Sci. 23 (3): 312-316.

Singh, A. K and Kavita, K. 2005. Effect of herbicides and mulching on growth and flowering parameters in rose. Journal of Ornamental Horticulture. 8 (1): 49-52.

Swaroop, K. Jankiram, T and Das, T. K. 2014. Flowering and corm yield of gladiolus cv. Jyotsna as influenced by pre-emergence application of different herbicides. International Journal of Tropical Agriculture. 32(1-2): 89-94.

Vijay Kumar and Patil, V. S. 2003. Effect of weed control treatments on flowering in Gladiolus. Journal of Ornamental Horticulture. 6 (4): 397-399.

Vinay Kumar, C and Gowada J. V. 2011. Effect of weed control methods on quality of China aster flower (Calistephus chinesis). International Journal of agriculture Science. 1: 109112.

\section{How to cite this article:}

Nagapushpa ,K., M. Vijaya, K.B. Suneetha Devi, A. Girwani and Veena Joshi. 2018. Effect of Different Herbicides on Floral and Yield Parameters in China aster (Callistephus chinensis (L.) Nees). Int.J.Curr.Microbiol.App.Sci. 7(05): 3284-3292.

doi: https://doi.org/10.20546/ijcmas.2018.705.384 